https://dx.doi.org/10.4314/ijs.v22i2.22

Ife Journal of Science vol. 22, no. 2 (2020)

\title{
TRANSFUSION-TRANSMISSIBLE VIRAL PATHOGENS AMONG BLOOD DONORS IN IBADAN, NIGERIA
}

\author{
Japhet, M. O. \\ Department of Microbiology, Faculty of Science, Obafemi Awolowo University, Ile-Ife, Nigeria. \\ E-mail: megdeoti@yahoo.com; Tel.: +2348037691786 \\ (Received: $2^{\text {nd }}$ May, 2020; Accepted: $26^{\text {th }}$ July, 2020)
}

\section{ABSTRACT}

\begin{abstract}
Transfusion-transmissible infections (TTIs), principally hepatitis B virus (HBV), hepatitis C virus (HCV) and human immunodeficiency virus (HIV) among blood donors remain a major threat to blood safety. The rate of viral infections in donated bloods plays a key role as the main indicator of blood safety, and this has to be monitored regularly. This study was designed to determine the prevalence of three viral pathogens among blood donors in Ibadan, South-western Nigeria. A total of 273 consenting blood donors, comprising of 246 males and 27 females, aged 18 to 60 years (mean age $=32.7$ years) were tested for the presence of HIV, HBV and HCV using commercially available Enzyme Immune Assay kits (EIA kits). Prevalence of 1.1\% (3/273), 5.1\% (14/273) and $0.4 \%(1 / 273)$ were recorded for HIV, HBV and HCV, respectively. Higher but not statistically significant $(\mathrm{P}>0.005)$ prevalence rates of the pathogens were recorded in the males. Also, all recorded infections occur among blood donors age 18 to 40 years. In summary, this study reports the presence of HIV, HBV and HCV among the blood donors and consequently confirm the need for improved screening procedures to reduce posttransfusion transmission of infection.
\end{abstract}

Keywords: HIV, Hepatitis B Virus, Hepatitis C virus, Blood transfusion, Co-infection, Transfusiontransmissible infections.

\section{INTRODUCTION}

Despite the necessity of blood products in certain medical circumstances, transfusion of unhealthy blood products can cause serious risks for the patients or even endanger their lives (Mohammadali and Pourfathollah, 2014). Human immunodeficiency virus (HIV), hepatitis B virus (HBV) and hepatitis $\mathrm{C}$ virus (HCV) are the greatest viral threats to blood safety especially in Africa (Spearman et al., 2017; Jary et al., 2019; Tigabu et al., 2019) because of their prolonged presence in the blood at a latent state (Tigabu et al., 2019). The three viruses share routes of transmission and many people with HIV are coinfected with HBV and HCV (Zhang et al., 2014).

Human immunodeficiency virus (HIV), hepatitis $\mathrm{B}$ and $\mathrm{C}$ virus infections contribute substantially to the global burden of viral diseases. Globally, 37.9 million [32.7-44.0 million] people were living with HIV at the end of 2018 with about 770, 000 deaths, and African region remains the most severely affected, accounting for more than twothirds of the people living with HIV worldwide and 470,000 of the $770,000 \mathrm{HIV}$-related deaths in 2018 (WHO, 2020). Hepatitis B is a global health problem, with an estimated 257 million people chronically hepatitis B-surface antigen ( $\mathrm{HBsAg}$ ) positive (WHO 2017). Globally, hepatitis B mortality is increasing, with 500000 to $1 \cdot 2$ million deaths occurring annually (Stanaway et al., 2016). Hepatitis $C$ virus infection is highly recognized as a major healthcare problem throughout the world and around 130 to 170 million people are chronic carriers of this virus globally (Tigabu et al., 2019).

In sub-Saharan Africa, percentage of collected blood units reactive for HIV in 2016 accounts for $0.10 \%-1.26 \%$ of HIV infections (Kanagasabai et al., 2018). The residual risk of transfusiontransmission of HBV varies worldwide, being greater in low and intermediate income countries, where the prevalence of the virus is higher (Prati and Valenti 2019). Transfusion-associated HCV has been reported as a major risk of $\mathrm{HCV}$ transmission (Biswas et al., 2018).

The rate of viral infections in donated bloods plays a key role as the main indicator of blood safety, which has to be monitored regularly. This study was therefore designed to determine the prevalence of HIV, HBV and HCV among blood donors in Ibadan, Southwest Nigeria. 


\section{MATERIALS AND METHODS}

\section{Study Population}

The study was carried out among 273 apparently healthy blood donors in Ibadan, Oyo state between October and December 2012. Ibadan is the capital and most populous city of Oyo State, Nigeria. It is the third most populous city in Nigeria after Lagos and Kano. Ibadan is located in the South-western part of Nigeria, $128 \mathrm{~km}$ inland northeast of Lagos and $530 \mathrm{~km}$ southwest of Abuja, the Federal Capital of Nigeria. The city ranges in elevation from $150 \mathrm{~m}$ in the valley area, to $275 \mathrm{~m}$ above sea level on the major north-south ridge which crosses the central part of the city. The city covers a total area of 3,080 square kilometres (1,190 sq mi), the largest in Nigeria.

\section{Sample Collection and Processing}

Blood sample $(5 \mathrm{ml})$ was collected by venepuncture from each blood donor into labelled sterile sample bottle, free of anticoagulants or preservative. Each blood specimen was separated by centrifugation at $3000 \mathrm{rpm}$ for 10 minutes to obtain serum. The serum was transferred aseptically into appropriately labelled cryovial and the sera kept at $-20^{\circ} \mathrm{C}$ until analysed.

\section{Laboratory Analysis}

The sera were screened for HIV antigen and antibody, hepatitis B surface antigen (HBsAg) and $\mathrm{HCV}$ antibodies (anti-HCV) using commercial Enzyme Immune Assay kits. For HIV, GENSCREEN ULTRA HIV Ag-Ab, (BIO-RAD, France), which detects HIV p24 antigen and HIV antibodies was used. Monolisa ${ }^{\mathrm{TM}}$ HBsAg ULTRA, (BIO-RAD, France), was used for HBV detection while detection of HCV antibodies was carried out using DIA-PRO HCV Ab EIA test kit, (Diapro Diagnotic Bioprobes Milano- Italy). Each assay was carried out according to manufacturer's instructions. The plates were read using a $450 \mathrm{~nm}$ filter microplate reader and results interpreted as directed by the test kit manufacturer.

\section{RESULTS}

\section{Socio-Demographic Characteristics of Blood Donors}

Of the 273 blood donors involved in the study, $246(90.1 \%)$ were males and $27(9.9 \%)$ were females. The age range of the blood donor was 18 70 years with a mean age of 32.7 years. The blood donors were grouped into six categories based on their ages: 18-20 (10 donors), 21-30 (111 donors), 31-40 (103 donors), 41-50 (39 donors), 51-60 (9 donors) and 61-70 (1 donor). The age and gender distribution of the blood donor is presented in table 1.

Table 1: Socio-demographic Characteristics of the Blood Donors

\begin{tabular}{lll}
\hline Age & Male Frequency $(\%)$ & Female Frequency $(\%)$ \\
\hline$<20(18-20)$ & $8(3.2 \%)$ & $2(7.4 \%)$ \\
$21-30$ & $98(39.8 \%)$ & $13(48.1 \%)$ \\
$31-40$ & $96(39.0 \%)$ & $7(25.9 \%)$ \\
$41-50$ & $35(14.2 \%)$ & $4(14.8 \%)$ \\
$51-60$ & $8(3.3 \%)$ & $1(3.7 \%)$ \\
$61-70$ & $1(0.4 \%)$ & $0(0 \%)$ \\
\hline Total & $246(90.1 \%)$ & $27(9.9 \%)$ \\
\hline
\end{tabular}

Seroprevalence of $\mathrm{HIV}, \mathrm{HBV}$ and $\mathrm{HCV}$ among Blood Donors

Of the 273 blood donors, 17 (6.2\%) had serological evidence of exposure to at least one of the viral pathogens tested. The overall prevalence rate of $\mathrm{HIV}, \mathrm{HBV}$, and $\mathrm{HCV}$ were 1.1\% (3/273), $5.1 \%(14 / 273)$ and $0.4 \%(1 / 273)$, respectively. There was no $\mathrm{HIV} / \mathrm{HCV}, \mathrm{HBV} / \mathrm{HCV}$ coinfection but a single HIV/HBV co-infection was observed (Figure 1). 


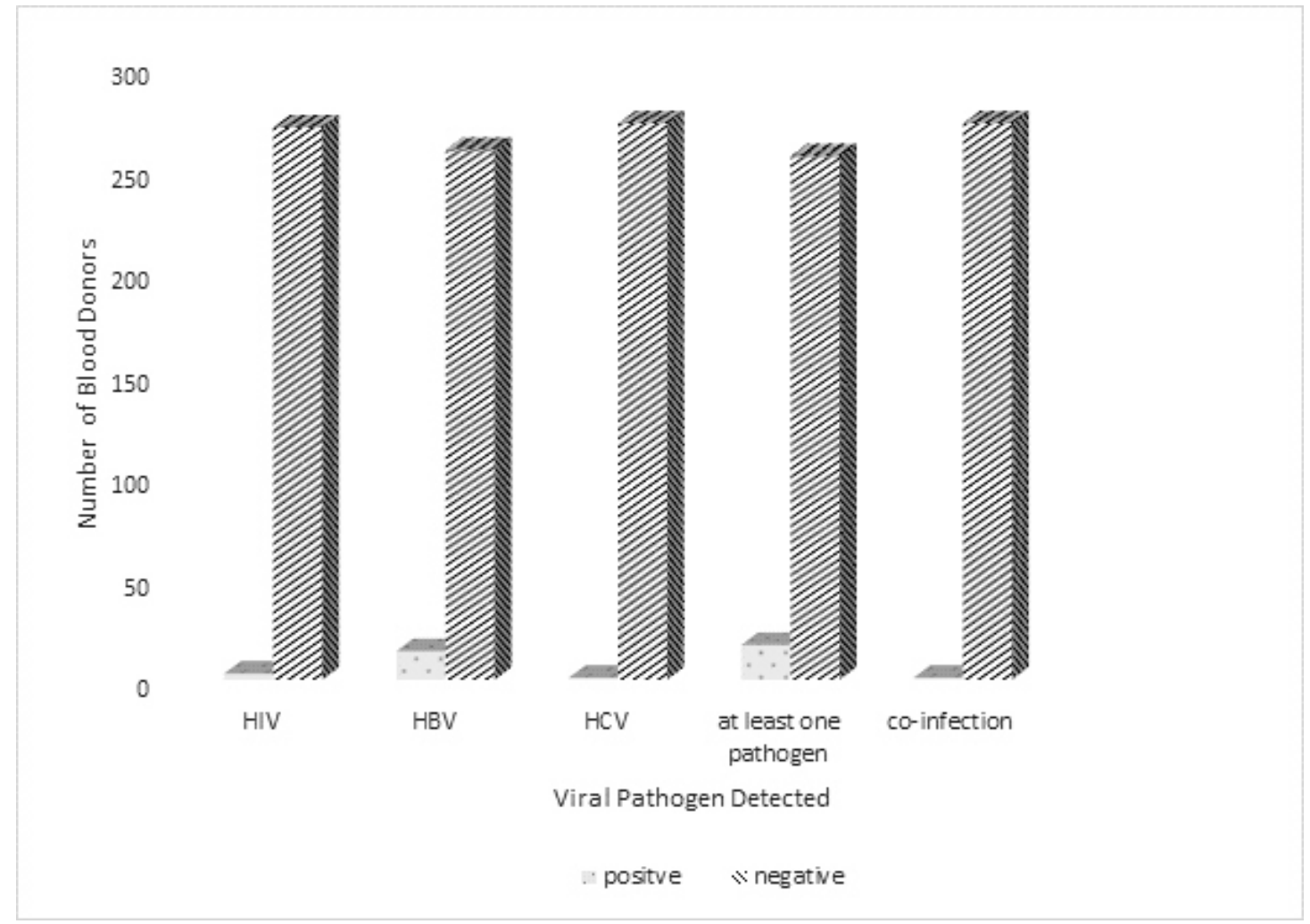

Figure 1: Seroprevalence of HIV, HBV, and HCV among the Bood Donors

\section{Gender and Age Distribution of HIV HBV and $\mathrm{HCV}$ among Blood Donors}

In this study, HIV, HBV and HCV prevalence were found to be higher in males than females but there was no statistical significance $(\mathrm{P}>0.005)$. All the HIV positive blood donors were males $(0$. 4\%). For HBsAg, 13 males (4.5\%) and $1(0.4 \%)$ female tested positive while the only $\mathrm{HCV}$ positive donor was a male $(0.4 \%)$. The $\mathrm{HIV} / \mathrm{HBV}$ co- infection was found in a male $(0.4 \%)$. All the HIV, HBV and HCV infection was found to occur among blood donors age 18 to 40 years, with highest HIV and HBV prevalence among blood donor in age range $21-30$ years and $31-40$ years, respectively while the HCV positive donor was a 40-year old male. None of the blood donors above aged 40 tested positive for any of the viruses (Table 2).

Table 2: Gender and Age Distribution of HIV, HBV and HCV among the Blood Donors

\begin{tabular}{lllll}
\hline Variable & NUMBER OF DONORS & HIV POSITIVE & HBV POSITIVE & HCV POSITIVE \\
\hline Male & $246(90.1 \%)$ & $3(100 \%)$ & 13 & 1 \\
Female & $27(9.9 \%)$ & $0(0 \%)$ & 1 & 0 \\
\hline Total & 273 & $3(1.1 \%)$ & $14(5.1 \%)$ & $1(0.4 \%)$ \\
\hline$<21(18-20)$ & $10(3.7 \%)$ & $2(66.7 \%)$ & $1(7.1 \%)$ & $0(0 \%)$ \\
$21-30$ & $111(40.7 \%)$ & $1(33.3 \%)$ & $2(14.3 \%)$ & $0(0 \%)$ \\
$31-40$ & $103(37.7 \%)$ & $0(0 \%)$ & $11(78.6 \%)$ & $1(100 \%)$ \\
$41-50$ & $39(14.3 \%)$ & $0(0 \%)$ & $0(0 \%)$ & $0(0 \%)$ \\
$51-60$ & $9(3.3 \%)$ & $0(0 \%)$ & $0(0 \%)$ & $0(0 \%)$ \\
$61-70$ & $1(0.4 \%)$ & $0(0 \%)$ & $0(0 \%)$ & $0(0 \%)$ \\
\hline Total & $273(100 \%)$ & $3(1.1 \%)$ & $14(5.1 \%)$ & $1(0.4 \%)$ \\
\hline
\end{tabular}




\section{DISCUSSION}

This study reports the prevalence of HIV, HBV, $\mathrm{HCV}$ and HIV/HBV co-infection among blood donors in Ibadan, a South-western city in Nigeria. It also reports high prevalence of blood borne viral infection among males compare to females as well as donors below 40 years of age. The prevalence of HIV, HBV and HCV was $1.1 \%$ $(3 / 273), 5.1 \%(14 / 273)$ and $0.4 \%(1 / 273)$ respectively.

About $90 \%$ of the recruited blood donors for this study were males. The reason for this may be because females are not encouraged to donate blood or may be exempted from blood donation due to anaemia, pregnancy, breastfeeding or childbirth. Nonetheless, most published studies among blood donors (Jeremiah et al., 2011; Motayo et al., 2015; Ogbolu et al., 2016; Okoroiwu et al., 2018; Jary et al., 2019; Tigabu et al., 2019) usually have a higher male to female ratio in the study population as found in this study.

Among the blood donors, the rate of serological evidence for at least one pathogen was $6.2 \%$, but higher prevalence rates of $19.3 \%$ has been documented in Nigeria (Okoroiwu et al., 2018), while Tigabu et al., 2019 recorded a closer prevalence rate of $8.2 \%$ among blood donors in Egypt. The decrease observed in this study may be as a result of the global trend resulting from improved control of sexually-transmitted infections and introduction of mandatory screening for Transfusion-transmissible Infections (TTI). In agreement with previous reports (Jeremiah et al., 2011; Motayo et al., 2015; Ogbolu et al., 2016; Tigabu et al., 2019) on the distribution of viruses causing greatest threat to blood safety, this study showed that HBV was most predominant $(5.1 \%)$, followed by $\mathrm{HIV}(1.1 \%$ ) and $\mathrm{HCV}(0.4 \%)$.

The published prevalence rates of HIV varies worldwide, depending on the country, study population, year of study and method used. In Nigeria, HIV prevalent rates reported from studies in Nigeria among different study population ranged from $2.6 \%$ to $6.5 \%$ Jeremiah et al., 2011; Motayo et al., 2015; Ogbolu et al., 2016; Okoroiwu et al., 2018) but this study shows a lower rate. Corroborating this lower prevalence is the 11-year HIV evaluation study among blood donors by Okoroiwu et al. (2018), who reported a sharp decline in HIV prevalence across the years from a score of $5.7 \%$ in the starting year (2005) to $1.7 \%$ in the ending year (2016), the earlier rise in HIV seroprevalence corresponding to the peak of HIV epidemic at the era when HIV was not recognized as public health concern. In addition, a prevalence as low as $0.1 \%$ has been recorded in the Eastern part of Africa among blood donors (Yusuf and Alemayehu, 2016).

Nigeria is considered a high HBV endemic regions since HBV chronic infection can be present in more than $8 \%$ of the population. A lower than $8 \%$ HBV prevalence reported in this study has been observed in other HBV studies in the country (Nwogoh et al., 2011; Onyekwere and Hameed 2015; Okoroiwu et al., 2018; Meka et al., 2019), possibly showing a decline in HBV prevalence in the country as a result of improved blood screening and banking system since introduction of mandatory screening for T'TI and launching of intervention programmes has been shown to reduce TTI (Mohammadali and Pourfathollah, 2014 ; Okoroiwu et al., 2018). The prevalence of HCV in this study is not far from $0.5 \%$ and $0.86 \%$ reported in Port Harcourt and Ile-Ife respectively in Nigeria (Erhabor, 2006; Salawu et al., 2010), although higher HCV prevalence rates among blood donors in the country have been reported before and after this study, ranging between 1.5\% to 3.6\% (Jeremiah et al., 2011; Motayo et al., 2015; Ogbolu et al., 2016; Okoroiwu et al., 2018). The reason for the irregular pattern of $\mathrm{HCV}$ prevalence in the country is unclear but may be due to differences in diagnostic techniques used in the studies; however the global seroprevalence of HCV among blood donors has been shown to vary from $0.4 \%$ to $19.2 \%$ (Mohammadali and Pourfathollah, 2014; Tigabu et al., 2019)

In relation to gender, males had higher prevalence of HIV, HBV and HCV compared to females, although there was no statistical correlation $(\mathrm{P}>0.005)$. This may be due to the higher male to female ratio $(10: 1)$ of the study population, although several studies with closer male to female ratio have also reported high $\mathrm{HIV}, \mathrm{HBV}$ and $\mathrm{HCV}$ prevalence among males compared to females in Nigeria (Ogbolu et al., 2016; Okoroiwu et al., 2018) 
and other African countries (Jary et al., 2019; Tigabu et al., 2019). Age distribution of HIV, HBV and HCV in the study shows that all the viral infections were found to occur among blood donors in age group 18 to 40 years. This finding is similar with published reports prior to and after this study in which higher prevalence of TTI was observed among the youths in the age groups of 18-45 years (Tessema et al., 2010; Bartonjo et al., 2019).

\section{CONCLUSION}

This study shows the presence of HIV, HBV and HCV as Transfusion- Transmissible Infection (TTI) among blood donors in the study population, dominated by male youths, between age group 18-40 years. Although a decline in the prevalence rate of these infections was observed in the study, there is the need for regular and proper screening of blood donors for these important pathogens as well as appropriate selection of blood donors using WHO donor selection guide, to achieve zero transfusion of infected blood since one infected blood could pose a major risk.

\section{REFERENCES}

Bartonjo, G., Oundo, J. and Ng'ang'a, Z. (2019). Prevalence and associated risk factors of transfusion transmissible infections among blood donors at regional blood transfusion center Nakuru and Tenwek Mission Hospital, Kenya. Pan African Medical Journal, 34:31.

Biswas, A., Firdaus, R., Saha, K., Chowdhury, P., Bhattacharya, D., Bhattacharyya, M. and Sadhukhan, P. C. (2018). Post-transfusion hepatitis $\mathrm{C}$ virus infection among âthalassaemic individuals with associated clinical parameters. Indian Journal of Medical Research, 147(6):581-587.

Erhabor, O., Ejele, O.A. and Nwanche, C.A. (2006). The risk of acquired hepatitis C virus infection among blood donors in Port Harcourt: the question of blood safety in Nigeria. Nigerian Journal of Clinical Practice, 9:18-21.

Jary, A., Dienta, S., Leducq, V. and Hingrat, Q.E. (2019). Seroprevalence and risk factors for HIV, HCV, HBV and syphilis among blood donors in Mali. BMC Infectious
Disease, 19(1):1064.

Jeremiah, Z.A., Idris, H., Ajayi, B.B., Ezimah, A.C., Malah, M.B. and Baba, M.M. (2011). Isolated anti-HBc-IgM antibody among blood donors in the semi-arid region of Nigeria. Human Antibodies, 20(3-4):77-82.

Kanagasabai, U, Chevalier, MS, Drammeh, B, Mili F. D., Qualls M. L., Bock N., Benech I., Nelson L. J., Alemnji G., Watts D. H., Kimani D., Selenic D (2018). Trends and gaps in national blood transfusion services - 14 sub-Saharan African countries, 2014- 2016. MMWR Morbidity Mortality Weekly Report, 67 (50):1392-1396.

Meka, I.A., Onodugo, O.D., Obienu, O., Okite, J. (2019) Hepatitis B surface antigenemia in two rural communities in Enugu, Nigeria. Niger J Clin Pract. 22(7):932-935.

Mohammadali, F. and Pourfathollah, A.A. (2014). Changes in frequency of HBV, HCV, HIV and syphilis infections among blood donors in Tehran province 2005-2011. Archives of Iranian Medicine, 17(9):613-620.

Motayo, B.O., Faneye, A.O., Udo, U.A., Olusola, B.A., Ezeani, I. and Ogiogwa, J.I. (2015). Seroprevalence of transfusion transmissible infections (TTI), in first time blood donors in Abeokuta, Nigeria. African Health Sciences, 15(1):19-24.

Nwogoh, B, Ikpomwen OD, Isoa EM (2011). Donor blood procurement and the risk of transfusion transmissible viral infections in a tertiary health facility in South-South Nigeria. Nigerian Medical Journal. 52(4):227-229.

Ogbolu, D.O., Alli, O.T., Odeleye, I. and Oluremi, A.S. (2016). High seroprevalence of asymptomatic viral haemoparasites among prospective blood donors in Nigeria. Asian Pacific Journal of Tropical Medicine, 9(7):658-661.

Okoroiwu, H.U., Okafor, I.M., Asemota, E.A. and Okpokam. D.C. (2018). Seroprevalence of transfusion-transmissible infections (HBV, HCV, syphilis and HIV) among prospective blood donors in a tertiary health care facility in Calabar, Nigeria; an eleven years evaluation. BMC Public Health, 18(645):1-8-

Onyekwere, C.A., Hameed, L. (2015). Hepatitis B 
and $\mathrm{C}$ virus prevalence and association with demographics: report of population screening in Nigeria. Tropical Doctor 45(4):231-235.

Prati, D. and Valenti, L. (2019). Uncovering occult Hepatitis B in blood donations: a tale of two worlds. Blood Transfusion, 17(6):399-400.

Salawu, L., Bolarinwa, R.A., Adegunloye, A.B. and Muraina, H.A. (2010). HBsAg, anti-HCV, anti-HIV and VDRL in blood donors: Prevalence and trends in the last three and a half years in a tertiary health care facility in Ile- Ife, Nigeria. International Journal of Medicine and Medical Sciences, 2(11): 335 341.

Spearman, C.W., Afihene, M., Ally, R., Apica, B., Awuku, Y., Cunha, L., Dusheiko, G., Gogela, N., Kassianides, C., Kew, M., Lam, P., Lesi, O., Lohouès-Kouacou, M. J., Mbaye, P. S., Musabeyezu, E., Musau, B., Ojo, O., Rwegasha, J., Scholz, B., Shewaye, A. B., Tzeuton, C., Sonderup, M. W (2017). Hepatitis B in sub-Saharan Africa: strategies to achieve the 2030 elimination targets. Lancet Gastroenterology and Hepatology. 2:900-909.

Stanaway, J.D., Flaxman, A.D., Naghavi, M., Fitzmaurice, C., Vos, T., Abubakar, I... and Cooke, G.S. (2016). The global burden of viral hepatitis from 1990 to 2013: findings from the global burden of disease study 2013. Lancet, 388:1081-1088

Tessema, B., Yismaw, G., Kassu, A., Amsalu, A., Mulu, A., Emmrich, F. and Sack, U. (2010). Seroprevalence of HIV, HBV, HCV and syphilis infections among blood donors at Gondar University Teaching Hospital,
Northwest Ethiopia: declining trends over a period of five years. BMC Infections Disease, 10(111): 1-7

Tigabu, A., Engda, T. and Mekonnen, F. (2019). Seroprevalence of transfusion transmissible viral infections (HIV, HBV and $\mathrm{HCV}$ ) among voluntary blood donors at University of Gondar Comprehensive Specialized Hospital, Gondar; Northwest Ethiopia. BMC Infectious Disease, 19(393):18.

WHO. 2017. Global Hepatitis Report (2017). Geneva: World Health Organization, April, 2017. www.who.int/hepatitis/ publications /globalhepatitisreport2017/en/ (Accessed July 24, 2017).

WHO. 2020. Summary of the Global HIV epidemic (2018). World Health Organization (C) WHO 2020. https://www.who.int/gho/hiv/en/ (Accessed April 24, 2020).

Yusuf, M. and Alemayehu, B. (2016). Seroprevalence of transfusion transmitted infection among blood donors of Jijiga blood bank, East Ethiopia; retrospective 4 years study. BMC Research Notes, 9(129):1-6.

Zhang, F., Zhu, H., Wu, Y., Dou, Z., Zhang, Y., Kleinman, N., Bulterys, M., Wu,Z., Ma, Y., Zhao, D., Liu, X., Fang, H., Liu, J., Cai, W., and Shang, H. (2014). HIV, Hepatitis B virus, and Hepatitis $\mathrm{C}$ virus co-infection in patients in the China national free antiretroviral treatment program, 201012: a retrospective observational cohort study. The Lancet Infectious Disease, 14(11):1065-1072. 